\title{
Utilization of Technology in Donuts Business
}

\author{
N D M Romauli*1), Himsar Ambarita ${ }^{2)}$, and Karina Nola Sinamo ${ }^{1)}$
}

${ }^{1}$ Food Science and Technology, Faculty of Agriculture, Kampus USU, Medan 20155

${ }^{2}$ Mechanical Engineering, Faculty of Engineering, Kampus USU, Medan 20155

\begin{abstract}
One of the purposes of community service activities is to help home industry to find solutions for the problem in running their businesses. Home industry have a lack of knowledge for the basic principles of food safety, such as donuts production's tools are very simple and they are not safe for food processing. They are also not familiar with online marketing and having limited information on how to re-use the remaining egg whites from the donuts production. The methods that used in this activity are the academic team having a visit to the location of the Home industry. Then,the team are designing and making equipment to assist the production process such as proofing cabinet and deep fryer machine. Interm of training, the team covered the topic on how importance of hygiene and sanitation of tools in producing food, the making of baking white egg based sponge cake and the installation of Instagram. After these activities, it is expected to grow the understanding and knowledge of the Home industry so that they can compete with other businesses running in the same field.
\end{abstract}

Keywords: Donuts, Deep fryer, Proofing cabinet, Hygiene, White egg cake

\begin{abstract}
Abstrak. Salah satu tujuan dari kegiatan program pengabdian kepada masyarakat adalah untuk membantu mencari solusi dalam permasalahan-permasalahan yang dihadapi mitra industri rumah tangga dalam mengembangkan usahanya. Mitra masih minim pengetahuan mengenai prinsip-prinsip dasar keamanan pangan dimana alat-alat yang digunakan selama ini masih sangat sederhana dengan kondisi yang sudah tidak aman dalam pengolahan pangan. Mereka juga belum terbiasa mengenai penjualan online dan kurang mengetahui cara pemanfaatan putih telur sisa dari hasil produksi donat. Metode yang digunakan dalam kegiatan ini adalah pendekatan kepada mitra industri rumah tangga. Kemudian tim mendesain dan membuat peralatan untuk membantu produksi berupa lemari proofing dan mesin deep fryer. Tim juga memberikan penyuluhan mengenai pentingnya hygenitas dan sanitasi alat-alat yang digunakan dalam memproduksi pangan, pembuatan bolu berbahan dasar putih telur dan pembuatan instagram. Setelah kegiatan pengabdian ini diharapkan akan meningkatkan pemahaman dan pengetahuan mitra industri rumah
\end{abstract}

*Corresponding author at: Food Science and Technology, Faculty of Agriculture, Jl. Prof A.Sofyan No 3, USU

E-mail address: nauas.romauli@usu.ac.id 
tangga sehingga bisa bersaing dengan usaha lain yang bergerak di bidang yang sama.

Kata Kunci: Donat, Alat penggorengan, Lemari proofing, Higenitas, Bolu putih telur Received 20 September 2019 | Revised 30 October 2019 | Accepted 15 November 2019

\section{Introduction}

The Home industry on this activity is running business on donut. The total daily production are made based on consumer requests, with a minimum production around 400-500 pieces per day. Depending on the size, the donuts are sold ranging from Rp 1000 rupiah to Rp 2000 per piece. The Home industry's biggest problem is the condition of production room,the remaining white egg, the limitation of knowledge about food safety and online marketing.

In terms of production room condition which is a room with rough cement floor, dirty walls and inside this room they also put an animal (a rooster and some hen) cage, which lead to unsafety food product, the condition is not fulfilled the minimum standard for donut business. Therefore, buyers sometimes cancelled their order of hundred pieces of donut after they came to visit the production room (Figure 1).

In the production room, all the dough are fermented for about 2-3 $\mathrm{h}$ inside the wooden shelf cabinet which is covered with a plastic sheet. Then the proofed donuts were fried in frying pan, fried on each side, then removed from the fryer and placed on a hand-made oil drained tools which made by wood and wire as seen as Figure 2. The fried donuts were then rearranged for cooling down in the previous used wooden shelf cabinet. The process is needed to ease the cake decoration with chocolate. The wooden shelf cabinet looks less sturdy, it is not made by material easy to clean, it is only covered by plastic sheet and it will makes the fermentation time become longer and too risky for contamination from the outside, such as dust and animals. Unfortunately, the wooden shelf cabinet and the frying tools were inappropriate to be applied in producing the food products.

Proofer cabinet is a cabinet that is used to encourage donuts fermentation in which the warm condition inside the chamber will support the expansion of donut dough and not causing it to dry. After the dough is mixed then it cut out into round shapes before it goes into the proofing cabinet. The dough should not be placed with heat exceeding $40^{\circ} \mathrm{C}$ because it cause the dough expand too quickly and produce large and rough pores. The bubbles on the donuts will occurs if there is too much moisture in the proofing 
cabinet [1]. The donut volume is significantly change during the baking of raw bread dough. The baking cause the dough is converted to a viscoelastic material containing airtight gas cells with the ability to expand to a rigid structure [2].

The other problem is the home industry are not optimizing the remaining eggwhites from donut's production, as the white egg can be used to make new product that are worth selling. In the manufacture of bakery products, whites egg make the hardness of the product. Compared to the yolk, white egg sometime become a waste of bakery production because the amount of egg white will be reduced or even will not used it at all. Egg white does have a bland taste, not as tasty as egg yolk. It turns out that not many people know that white egg also have good nutritional content for health, that in every $100 \mathrm{~g}$ of white egg contains of $10.3 \mathrm{~g}$ of protein, $0.65 \mathrm{~g}$ of carbohydrates and $0.03 \mathrm{~g}$ of fat and contains $1-15 \mathrm{mg}$ of calcium [3]. White egg can be used to make a variety of cakes with delicious taste as tasty as cakes that use egg yolk ingredients [4].

Finally, the partner experiences limitation knowledge on the basic principle of food safety and the ability to increase the costomer's order. On daily donuts production, Home industry still use tools that are not safe for food processing, only do offline marketing. Nowadays, the internet becomes the main need of people's activity such as browsing and searching for information, watching movies, having fun through social media, keeping in touch with old or new friends. Moreover, the internet can also be used as an income source, such as by having Instagram application. Instagram is a social media that facilitates its user to share their best photo. Therefore, this social media very usefull and easier for online shop players to be able to increase their sales [5].

The expected objective of community service is that home industry can produce food product that is safe for consumption, gaining more public trust of their selling product, having the ability to compete with other businesses running in the same field with new selling product and doing online marketing.

\section{Methods}

The activity methods are the academic team having a visit to the location of the Home industry in Padang Bulan Selayang, Medan Selayang subdistrict. Then, both parties are discussing, designing and making equipments to support safer food processing according to the observation, Academic team are also advicing about the importance of hygiene and sanitation in food production, training of baking egg white-based sponge cake and training of making Instagram. The equipment used in this activity to support 
Partner's business were: (1) a designed proofing cabinet, (2) a designed deep fryer machine and (3) a standing mixer.

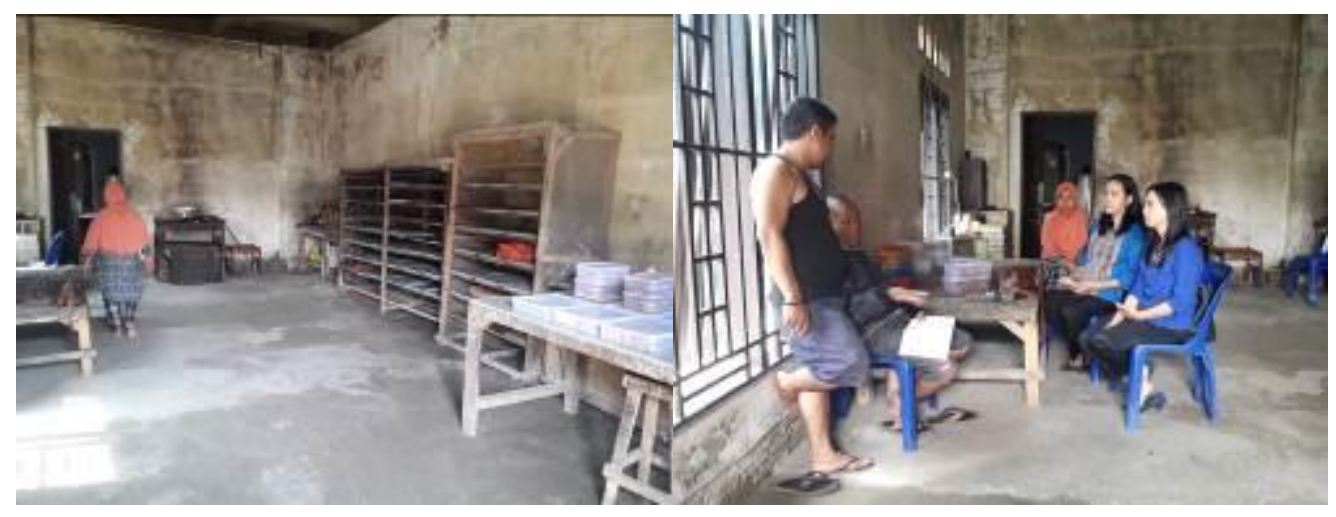

Figure 1. (Left) Previous condition of donuts production room. (Right) The home industry's problems were discussed with the academic team

\section{Results and Discussion}

BPOM Regulation (2012) on concerning about the basic principles of food safety for food home industry mention several rules that must be fulfilled to produce safe and good quality food products, Some of the instruction are home industry location must be kept clean to protect the food product, the building and facilities can quarantee the food product will not polluted by physical, biological and chemical hazards during the production process, production equipment have to designed and constructed to easy to be cleaned and sanitize to ensure the quality and food safety and etc [6]. Consequently, public trust to have their product can increase as the food product is safer for consumption. The positive impact of this activities are the Home industry have great motivation to have a better donut's production room. They also initiate the changing of the production space from a room with rough cement floor to a room with ceramic floor (Figure 3).

The impact of areas surrounding the production also significant for product quality, but baking process also needs of individual stages and technological operations which when operating properly will gave a good product [7]. A designed proofing cabinet and deep fryer machine gave a lot of advantages for Home industry. Dough characteristic are very important in stages moulding and frying process because they determine the good quality of the final product. Many physicochemical changes take place during frying process that can develop the characteristic of fried foods such as browning or crust formation. By using deep frying gave advantages, 
i.e. speed of cooking, consistency of cooked product, energy efficiency and can gave color, flavor and crisp texture. One of the most important physical change during donuts production is the crust darkening which it is should be controlled to avoid consumer rejection $[8,9]$.

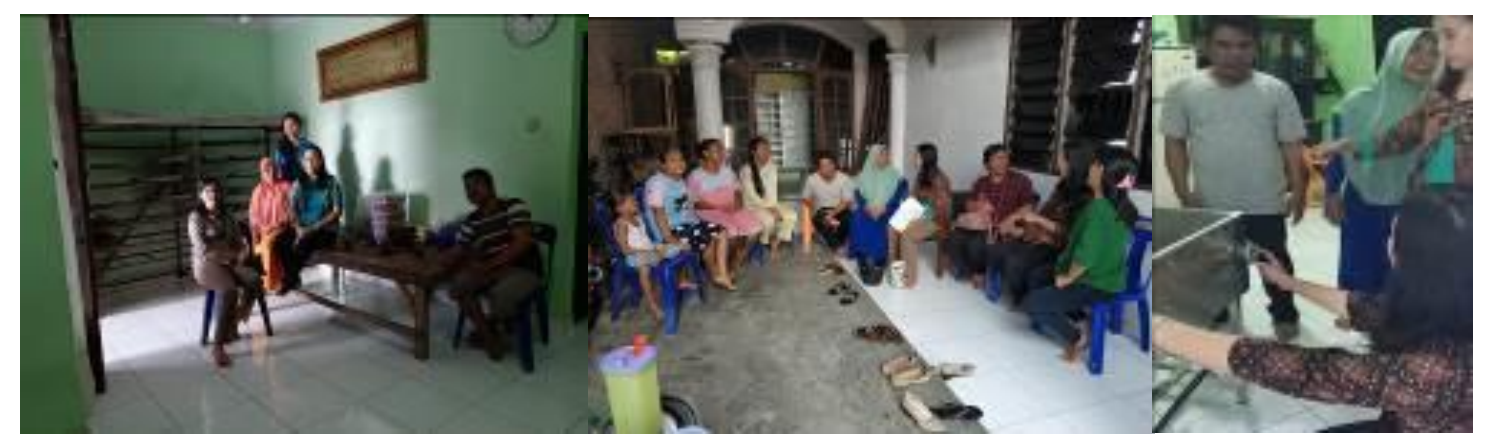

Figure 3. (Left) the new production room; (Center) Team gave counceling about the importance of hygiene and sanitation in producing food; (Right) Team explained how to use the deep fryer machine

On daily basis, a minimum donut production per day was around 400-500 pieces by using $6 \mathrm{~kg}$ of Cakra kembar flour with $24 \mathrm{egg}$ yolks. Then Home industry consume some of the egg white for their family dinner, while the remaining white egg become wasted. Therefore, team gave an idea and training to use the leftover white eggs become a new selling product, i.e white egg based sponge cake. In addition, to increase the costumer's order, the team also help partner to make an instagram of their donut business, named "syaiban_donat", along with support on how to post a photo on instagram (Figure 4).

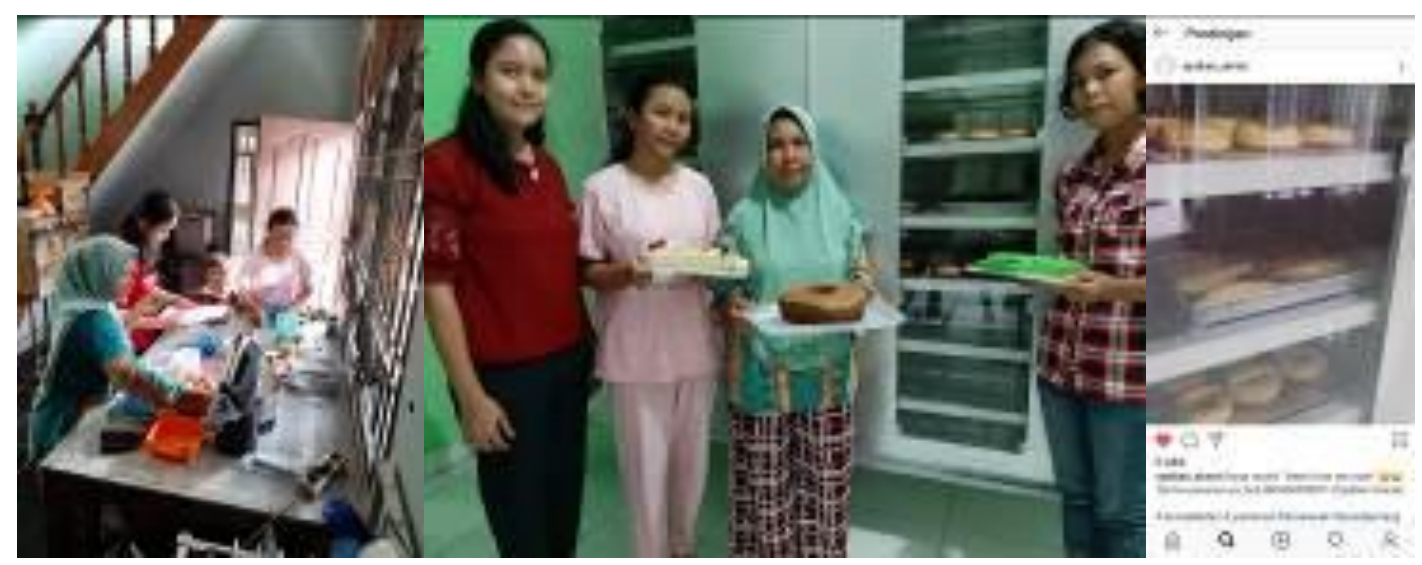

Figure 4. (Left) Team gave training of baking white egg based sponge cake and making Instagram; (Center) Partner shows the white egg cake; (Right) Instagram of partner's donut business

The success of this activity can be seen from the ability of home industry adopt of the appropriate technology to use proofing cabinet, deep fryer machine and standing mixer 
to support the Home industry's business (Figure 5). Home industry can accept all the suggestions and have an initiative to change the production space become the better condition room. The achieved outcome after finalising this activities are the increase in consumer's order which lead to the improvement on the Home industry's income.

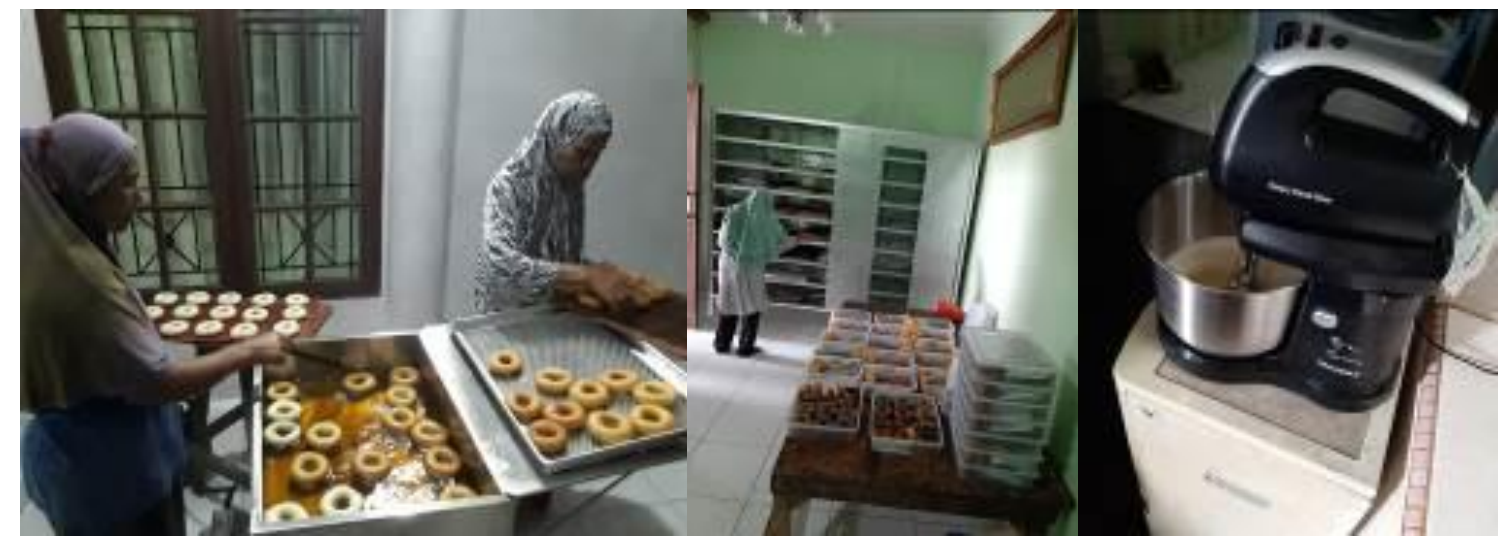

Figure 5. Implementation of community service activities

\section{Conclusions}

After introducing several technologies to home industry's donuts business, the production room looks more hygenic and safer. Home industry can have more product variation to sell and expand their marketing target through a media social. It is expected that this activity can give a positive impact to the surrounding community.

\section{Acknowledgement}

Author would like to acknowledge the support of Non PNBP Universitas Sumatera Utara for this activities under grant 327/UN5.2.3.2.1/PPM/2019.

\section{References}

[1] Makmoer, H. 2006. Seri Resep Ahli Bakery: Roti Manis dan Donat (Bakery Expert Recipes Series: Sweet Bread and Donuts). PT Gramedia Pustaka Utama, 92 halaman. [In Indonesian]

[2] Hui, Y. H. 2006. Handbook of Food Science, Technology and Engineering. CRC Press, 148 page.

[3] Nugraheni, M. 2013. Pengetahuan Bahan Pangan Hewani (Animal food science) Graha Ilmu. Yogyakarta, 218 halaman. [In Indonesian]

[4] Winijarti. 2007. Aneka Cake dari Putih Telur (Assorted Egg White Cake). Tiara Aksa Surabaya, 18 halaman. [In Indonesian]

[5] Evans, D. 2008. Social Media Marketing: An Hour a Day. John Wiley Publishing, Inc, 380 pages.

[6] Peraturan Kepala Badan Pengawas Obat dan Makanan Republik Indonesia. 2012. Cara Produksi Pangan yang Baik untuk Industri Rumah Tangga (Good Food Production Methods for Home Industry). Nomor HK.03.1.23.04.12.2206. [In 
Indonesian]

[7] Przystupa, K. 2018. The Methods Analysis of Hazards and Product Defects in Food Processing. Czech Journal of Food Science, 37(1): 44-50.

[8] Oke, E.K., M.A. Idowu, O.P. Sobukola, S.A.O. Adeyeye, A.O. Akinsola. 2018. Frying of Food: A Critical Review. Journal of Culinary Science and Technology, 16(2): 107-127.

[9] Arief, U.M, D.N. Setyaningsih, S. Purbawanto. 2018. Upaya Peningkatan Produksi Dengan Menggunakan Alat Pengaduk Otomatis Pada Usaha Donat Kentang di Semarang (The effort To Increase The Production By Using An Automatic Stirrer At Potato Donut Business In Semarang). Abdimas, 22(1): 103-110. [In Indonesian] 